\title{
Delicate Difference in Coordinating Nature between Copper(II) and Nickel(II) Ions. Structural Properties of Copper(II) and Nickel(II) Nitrate Containing 1,2-Bis(dimethyl-3-pyridylsilyl)ethane
}

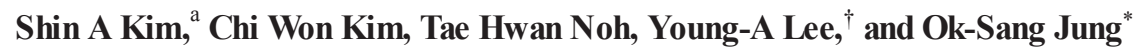 \\ Department of Chemistry, Pusan National University, Pusan 609-735, Korea. *E-mail: oksjung@pusan.ac.kr \\ ${ }^{\dagger}$ Department of Chemistry, Chonbuk National University, Jeonju 561-756, Korea \\ Received March 16, 2010, Accepted June 4, 2010
}

\begin{abstract}
Studies on the molecular construction and structures of $\mathrm{M}\left(\mathrm{NO}_{3}\right)_{2}(\mathrm{M}=\mathrm{Cu}(\mathrm{II}), \mathrm{Ni}(\mathrm{II}))$ complexes with 1,2-bis(dimethyl-3-pyridylsilyl)ethane (L) have been carried out. Formation of each molecular skeleton appears to be primarily associated with a suitable combination of bidentate $N$-donors of $\mathrm{L}$ and coordinating nature of octahedral metal(II) ions: $\left[\mathrm{Cu}\left(\mathrm{NO}_{3}\right)_{2}(\mathrm{~L})_{2}\right]$ yields a 2-dimensional sheet structure consisting of 44 -membered $\mathrm{Cu}_{4} \mathrm{~L}_{4}$ skeleton whereas $\left[\mathrm{Ni}(\mathrm{L})_{2}\left(\mathrm{H}_{2} \mathrm{O}\right)_{2}\right]\left(\mathrm{NO}_{3}\right)_{2}$ produces an interpenetrated 3-dimensional structure consisting of 66-membered cyclohexanoid $\left(\mathrm{M}_{6} \mathrm{~L}_{6}\right)$ skeleton. The $\mathrm{Cu}(\mathrm{II})$ ion prefers nitrate whereas the Ni(II) ion prefers water molecules as the fifth and the sixth ligands.
\end{abstract}

Key Words: 1,2-Bis(dimethyl-3-pyridylsilyl)ethane, Coordinating nature, Copper(II), Interpenetration, Nic$\operatorname{kel}(\mathrm{II})$

\section{Introduction}

A thematic issue in the molecular construction of coordination polymers is the understanding of weak serendipitous interactions that give rise to intriguing supramolecular motifs, crystal packing, and specific photophysical properties. ${ }^{1-6}$ Such noncovalent interactions have often been studied to deduce general structure-stability relationships and delicate difference, and the results can be extended beyond the initial goal to diverse areas such as quantum mechanical calculations, spectroscopic studies, molecular biology, and recognition materials. ${ }^{7,8}$ In particular, induction of high dimension is emerging as an important field owing to various potential applications such as molecular separation, toxic materials adsorption, molecular containers, ion exchangers, molecular recognition, and luminescent sensors. ${ }^{9-13}$ Thus, various kinds of framework materials have been constructed by the coordinations of metal ions with appropriate spacer ligands. ${ }^{2,12,14-22}$ The molecular geometry and flexibility of multidentate $N$-donor spacer ligands play indispensible roles in the development of the tailor-made molecular materials. Recently, we have demonstrated that various silicon-containing pyridyl spacers are useful for the synthesis of task-specific skeletal structures, ${ }^{20-23}$ since the ligands have been known to be adjustable in their potential bridging ability, flexible interligand angles at silicon, and conformers, in addition to the inductive and steric effects of the silicon atom. ${ }^{24}$

In order to explore subtle difference between nickel(II) and copper(II) ions on molecular construction, we report the structures and related properties of the metal complexes prepared by the reaction of $\mathrm{MX}_{2}(\mathrm{M}=\mathrm{Ni}(\mathrm{II}), \mathrm{Cu}(\mathrm{II}))$ with 1,2-bis(dimethyl-3-pyridylsilyl)ethane (L). $\mathrm{L}$ is a spacer ligand that possesses a flexible alkyl chain between two pyridine rings,

${ }^{a}$ Present address: Department of Chemistry, Korea Air Force Academy, Chungbuk 363-840, Korea thereby imparting a conformational nonrigidity to the pyridyl groups. According to our previous report, ${ }^{25}$ the ligand could be acted as either a cisoidal or a transoidal orientation.

\section{Experimental Section}

Materials and measurements. $\mathrm{Cu}\left(\mathrm{NO}_{3}\right)_{2} \cdot 3.5 \mathrm{H}_{2} \mathrm{O}$ and $\mathrm{Ni}$ $\left(\mathrm{NO}_{3}\right)_{2} \cdot 6 \mathrm{H}_{2} \mathrm{O}$ were purchased from Aldrich, and were used without further purification. 1,2-Bis(dimethyl-3-pyridylsilyl) ethane (L) was prepared by the literature method. ${ }^{25}$ Elemental microanalyses $(\mathrm{C}, \mathrm{H}, \mathrm{N})$ were performed on crystalline samples by the Pusan Center at KBSI using a Vario-EL III. Infrared spectra were obtained on a Nicolet 380 FT-IR spectrophotometer with samples prepared as $\mathrm{KBr}$ pellets.

$\left[\mathrm{Cu}\left(\mathrm{NO}_{3}\right)_{2}(\mathrm{~L})_{2}\right] \cdot \mathbf{2} \mathrm{CH}_{3} \mathrm{OH}$. A methanol solution $(2 \mathrm{~mL})$ of $\mathrm{L}$ (15.0 mg, $0.05 \mathrm{mmol}$ ) was slowly diffused into an aqueous solution $(2 \mathrm{~mL})$ of $\mathrm{Cu}\left(\mathrm{NO}_{3}\right)_{2} \cdot 3.5 \mathrm{H}_{2} \mathrm{O}(4.69 \mathrm{mg}, 0.025 \mathrm{mmol})$. Light blue crystals of $\left[\mathrm{Cu}\left(\mathrm{NO}_{3}\right)_{2}(\mathrm{~L})_{2}\right]$ formed at the interface, and were obtained in 6 days in an $81 \%$ yield $(17.3 \mathrm{mg})$. Anal. Calcd for $\mathrm{C}_{32} \mathrm{H}_{48} \mathrm{~N}_{6} \mathrm{O}_{6} \mathrm{Si}_{4} \mathrm{Cu}: \mathrm{C}, 48.73 ; \mathrm{H}, 6.13 ; \mathrm{N}, 10.66$. Found: $\mathrm{C}, 48.60$; $\mathrm{H}, 6.10 ; \mathrm{N}, 10.20$. The crystals were obtained as methanol solvate, but the elemental analysis was accomplished after desolvation under vacuum owing to the partial evaporation of solvate methanol molecules. IR (KBr, cm $\left.{ }^{-1}\right): v\left(\mathrm{NO}_{3}\right), 1392$ (s).

$\left[\mathbf{N i}(\mathbf{L})_{2}\left(\mathbf{H}_{2} \mathbf{O}\right)_{2}\right]\left(\mathbf{N O}_{3}\right)_{2}$. A methanol solution $(3 \mathrm{~mL})$ of $\mathrm{L}(15.0$ $\mathrm{mg}, 0.05 \mathrm{mmol})$ was slowly diffused into an aqueous solution $(3 \mathrm{~mL})$ of $\mathrm{Ni}\left(\mathrm{NO}_{3}\right)_{2} \cdot 6 \mathrm{H}_{2} \mathrm{O}(7.27 \mathrm{mg}, 0.025 \mathrm{mmol})$. Greenish crystals of $\left[\mathrm{Ni}(\mathrm{L})_{2}\left(\mathrm{H}_{2} \mathrm{O}\right)_{2}\right]\left(\mathrm{NO}_{3}\right)_{2}$ formed at the interface, and were obtained in 6 days in a $79 \%$ yield $(16.2 \mathrm{mg})$. Anal. Calcd for $\mathrm{C}_{32} \mathrm{H}_{52} \mathrm{~N}_{6} \mathrm{O}_{8} \mathrm{Si}_{4} \mathrm{Ni}$ : C, 46.88; H, 6.39; N, 7.16. Found: $\mathrm{C}$, 46.50; H, 6.21; N, 7.10. IR ( $\left.\mathrm{KBr}, \mathrm{cm}^{-1}\right)$ : $v\left(\mathrm{NO}_{3}\right), 1384$ (s).

Crystallographic structure determinations. X-ray data were collected on a Bruker SMART automatic diffractometer with a graphite-monochromated Mo K $\alpha$ radiation $(\lambda=0.71073 \AA)$ and a CCD detector at ambient temperature. The 36 frames of 
Table 1. Crystal data for $\left[\mathrm{Cu}\left(\mathrm{NO}_{3}\right)_{2}(\mathrm{~L})_{2}\right]$ and $\left[\mathrm{Ni}(\mathrm{L})_{2}\left(\mathrm{H}_{2} \mathrm{O}\right)_{2}\right]\left(\mathrm{NO}_{3}\right)_{2}$

\begin{tabular}{lll}
\hline & {$\left[\mathrm{Cu}\left(\mathrm{NO}_{3}\right)_{2}(\mathrm{~L})_{2}\right] \cdot 2 \mathrm{CH}_{3} \mathrm{OH}$} & {$\left[\mathrm{Ni}(\mathrm{L})_{2}\left(\mathrm{H}_{2} \mathrm{O}\right)_{2}\right]\left(\mathrm{NO}_{3}\right)_{2}$} \\
\hline Formula & $\mathrm{C}_{34} \mathrm{H}_{56} \mathrm{~N}_{6} \mathrm{O}_{8} \mathrm{Si}_{4} \mathrm{Cu}$ & $\mathrm{C}_{32} \mathrm{H}_{52} \mathrm{~N}_{6} \mathrm{O}_{8} \mathrm{Si}_{4} \mathrm{Ni}$ \\
Weight & 852.75 & 819.87 \\
Crystal system & Orthorhombic & Tetragonal \\
Space group & $P$ ccn & $I 4{ }_{1} /$ acd \\
$a / \AA$ & $22.7583(2)$ & $22.9094(1)$ \\
$b / \AA$ & $23.0731(2)$ & $22.9094(1)$ \\
$c / \AA$ & $16.3886(1)$ & $16.3322(2)$ \\
$V / \AA^{3}$ & $8605.7(1)$ & $8571.8(1)$ \\
$Z$ & 8 & 8 \\
$\mu /$ mm & 8.672 & 0.615 \\
$F(000)$ & 3608 & 3472 \\
Reflections collected & 47625 & 23102 \\
Independent reflections & $8462[R($ int $)=0.1905]$ & $2111[R($ int $)=0.0948]$ \\
Completeness & $100.0 \%\left(\theta=26.00^{\circ}\right)$ & $99.8 \%\left(\theta=25.98^{\circ}\right)$ \\
GOF on $F^{2}$ & 1.074 & 1.097 \\
Final $R[I>2 \sigma(I)]$ & ${ }^{a} R_{1}=0.0768,{ }^{b} w R_{2}=0.1810$ & $R_{1}=0.0841, w R_{2}=0.2132$ \\
$R($ all data $)$ & $R_{1}=0.1961, w R_{2}=0.2784$ & $R_{1}=0.1079, w R_{2}=0.2455$ \\
\hline
\end{tabular}

${ }^{a} R_{1}=\Sigma|| \mathrm{F}_{\mathrm{o}}|-| \mathrm{F}_{\mathrm{c}}|| \Sigma\left|\mathrm{F}_{\mathrm{o}}\right|,{ }^{b} w R_{2}=\left\{\Sigma\left[\mathrm{w}\left(\mathrm{F}_{\mathrm{o}}{ }^{2}-\mathrm{F}_{\mathrm{c}}{ }^{2}\right)^{2}\right] / \Sigma\left[\mathrm{w}\left(\mathrm{F}_{\mathrm{o}}{ }^{2}\right)^{2}\right]\right\}^{1 / 2}$.

two dimensional diffraction images were collected and processed to obtain the cell parameters and orientation matrix. The data were corrected for Lorentz and polarization effects. Absorption effects were corrected by the SADABS method. The structures were solved by the direct method (SHELXS 97) and refined by full-matrix least squares techniques (SHELXL 97). ${ }^{26}$ The non-hydrogen atoms were refined anisotropically, and hydrogen atoms were placed in calculated positions and refined only for the isotropic thermal factors. Crystal parameters and procedural information corresponding to data collection and structure refinement are given in Table 1. Crystallographic data for the structures reported here have been deposited with the Cambridge Crystallographic Data Centre (CCDC-769614 and 769615). The data can be obtained free of charge via http://www.ccdc.cam. ac.uk/perl/catreq/catreq.cgi (or from the CCDC, 12 Union Read, Cambridge CB2 1EZ, UK; fax: +44 1233 336033; e-mail: deposit@ccdc.cam.ac.uk).

\section{Results and Discussion}

Synthesis. The slow diffusion of an organic solution of 1,2bis(dimethyl-3-pyridylsilyl)ethane (L) into an aqueous solution of $\mathrm{M}\left(\mathrm{NO}_{3}\right)_{2}(\mathrm{M}=\mathrm{Cu}(\mathrm{II}), \mathrm{Ni}(\mathrm{II}))$ afforded different adducts, presumably owing to the different coordinating nature of the metal ions. The copper(II) complex was obtained as methanol solvate of $\left[\mathrm{Cu}\left(\mathrm{NO}_{3}\right)_{2}(\mathrm{~L})_{2}\right] \cdot 2 \mathrm{CH}_{3} \mathrm{OH}$ whereas the nickel complex was given as $\left[\mathrm{Ni}(\mathrm{L})_{2}\left(\mathrm{H}_{2} \mathrm{O}\right)_{2}\right]\left(\mathrm{NO}_{3}\right)_{2}(\mathrm{Scheme} 1)$. The slow diffusion reactions were originally conducted in the $1: 2$ mole ratio of the metal ions and L, but the products were not significantly affected by the mole ratio. The crystalline products are insoluble stable in water and common organic solvents, and are stable for several days even in aqueous suspensions.

Crystal structures. The crystal structure of $\left[\mathrm{Cu}\left(\mathrm{NO}_{3}\right)_{2}(\mathrm{~L})_{2}\right]$. $2 \mathrm{CH}_{3} \mathrm{OH}$ is shown in Figures 1 and 2, and relevant bond distances and angles are listed in Table 2 . The X-ray crystallo-

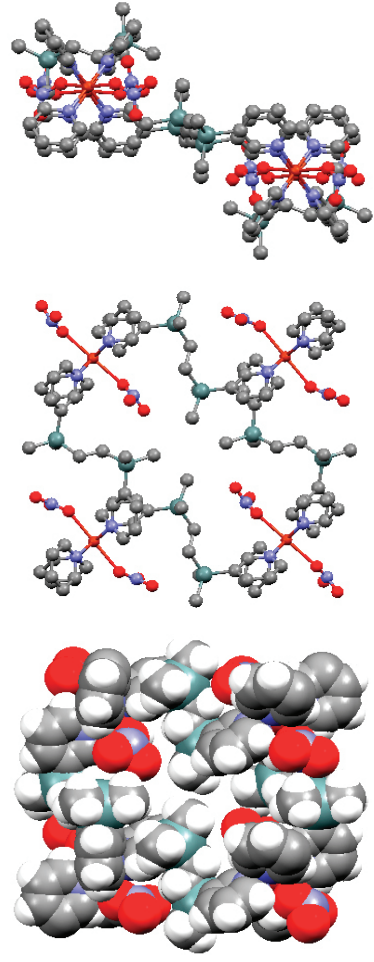

Figure 1. Ball-and-stick drawings in $a$-axis (Top) and $c$-axis (middle) view, and the space-filling drawing (bottom) of skeletal unit of $\left[\mathrm{Cu}\left(\mathrm{NO}_{3}\right)_{2}(\mathrm{~L})_{2}\right] \cdot 2 \mathrm{CH}_{3} \mathrm{OH}$. Hydrogen atoms, except for bottom, and solvated methanol molecules have been omitted for clarity.

graphic characterization revealed that the product affords an $\left(4^{4}\right)\left(6^{2}\right)$-isc net. ${ }^{27}$ There are two copper(II) ions in the asymmetric units. Each L connects two copper(II) ions in a transoidal fashion to yield a 2-dimensional sheet structure consisting of 44-membered rectangular $\mathrm{Cu}_{4} \mathrm{~L}_{4}$ skeletons. The $\mathrm{Cu} \cdots \mathrm{Cu}$ separations through L are 11.382(1) $\AA$ and 12.491(1) $\AA$, and the 
Table 2. Relevant bond lengths $(\AA)$ and angles $\left({ }^{\circ}\right)$ for $\left[\mathrm{Cu}\left(\mathrm{NO}_{3}\right)_{2}(\mathrm{~L})_{2}\right]$ and $\left[\mathrm{Ni}(\mathrm{L})_{2}\left(\mathrm{H}_{2} \mathrm{O}\right)_{2}\right]\left(\mathrm{NO}_{3}\right)_{2}$

\begin{tabular}{|c|c|c|c|c|c|}
\hline \multicolumn{4}{|c|}{$\left[\mathrm{Cu}\left(\mathrm{NO}_{3}\right)_{2}(\mathrm{~L})_{2}\right] \cdot 2 \mathrm{CH}_{3} \mathrm{OH}$} & \multicolumn{2}{|c|}{$\left[\mathrm{Ni}(\mathrm{L})_{2}\left(\mathrm{H}_{2} \mathrm{O}\right)_{2}\right]\left(\mathrm{NO}_{3}\right)_{2}$} \\
\hline $\mathrm{Cu}(1)-\mathrm{N}(2)$ & $2.028(7)$ & $\mathrm{Cu}(2)-\mathrm{N}(1)$ & $2.033(7)$ & $\mathrm{Ni}(1)-\mathrm{N}(1)$ & $2.097(4)$ \\
\hline $\mathrm{Cu}(1)-\mathrm{N}(3)$ & $2.034(7)$ & $\mathrm{Cu}(2)-\mathrm{N}(4)$ & $2.010(7)$ & $\mathrm{Ni}(1)-\mathrm{O}(4)_{\mathrm{w}}$ & $2.107(5)$ \\
\hline $\mathrm{Cu}(1)-\mathrm{O}(4)$ & & $\mathrm{Cu}(2)-\mathrm{O}(1)$ & $2.427(6)$ & & \\
\hline $\mathrm{N}(2)-\mathrm{Cu}(1)-\mathrm{N}(2)^{\# 1}$ & $91.8(4)$ & $\mathrm{N}(1)^{\# 2}-\mathrm{Cu}(2)-\mathrm{N}(4)$ & $89.7(3)$ & $\mathrm{N}(1)-\mathrm{Ni}(1)-\mathrm{N}(1)^{\# 5}$ & $89.2(2)$ \\
\hline $\mathrm{N}(2)^{\# 1}-\mathrm{Cu}(1)-\mathrm{N}(3)$ & $89.7(3)$ & $\mathrm{N}(1)^{\# 2}-\mathrm{Cu}(2)-\mathrm{N}(1)^{\# 3}$ & $89.0(4)$ & $\mathrm{N}(1)^{\# 5}-\mathrm{Ni}(1)-\mathrm{N}(1)^{\# 6}$ & $90.9(2)$ \\
\hline $\mathrm{N}(2)-\mathrm{Cu}(1)-\mathrm{N}(3)$ & $177.8(3)$ & $\mathrm{N}(1)^{\# 2}-\mathrm{Cu}(2)-\mathrm{N}(4)^{\# 4}$ & $178.1(3)$ & $\mathrm{N}(1)-\mathrm{Ni}(1)-\mathrm{N}(1)^{\# 6}$ & $177.8(2)$ \\
\hline $\mathrm{O}(4)-\mathrm{Cu}(1)-\mathrm{N}(2)$ & $90.1(3)$ & $\mathrm{O}(1)-\mathrm{Cu}(2)-\mathrm{N}(1)^{\# 2}$ & $88.6(2)$ & $\mathrm{N}(1)-\mathrm{Ni}(1)-\mathrm{O}(4)_{\mathrm{w}}$ & $91.10(1)$ \\
\hline $\mathrm{O}(4)-\mathrm{Cu}(1)-\mathrm{N}(3)$ & $86.2(3)$ & $\mathrm{O}(1)-\mathrm{Cu}(2)-\mathrm{N}(1)^{\# 3}$ & $85.9(2)$ & $\mathrm{N}(1)^{\# 5}-\mathrm{Ni}(1)-\mathrm{O}(4)_{\mathrm{w}}$ & $88.90(1)$ \\
\hline $\mathrm{O}(4)-\mathrm{Cu}(1)-\mathrm{N}(3)^{\# 1}$ & $88.6(3)$ & $\mathrm{O}(1)-\mathrm{Cu}(2)-\mathrm{N}(4)$ & $95.4(3)$ & & \\
\hline
\end{tabular}

$\# 1-x+3 / 2,-y+3 / 2, z \# 2-x+1,-y+1,-z+1 \# 3 x+1 / 2, y-1 / 2,-z+1 \# 4-x+3 / 2,-y+1 / 2, z$

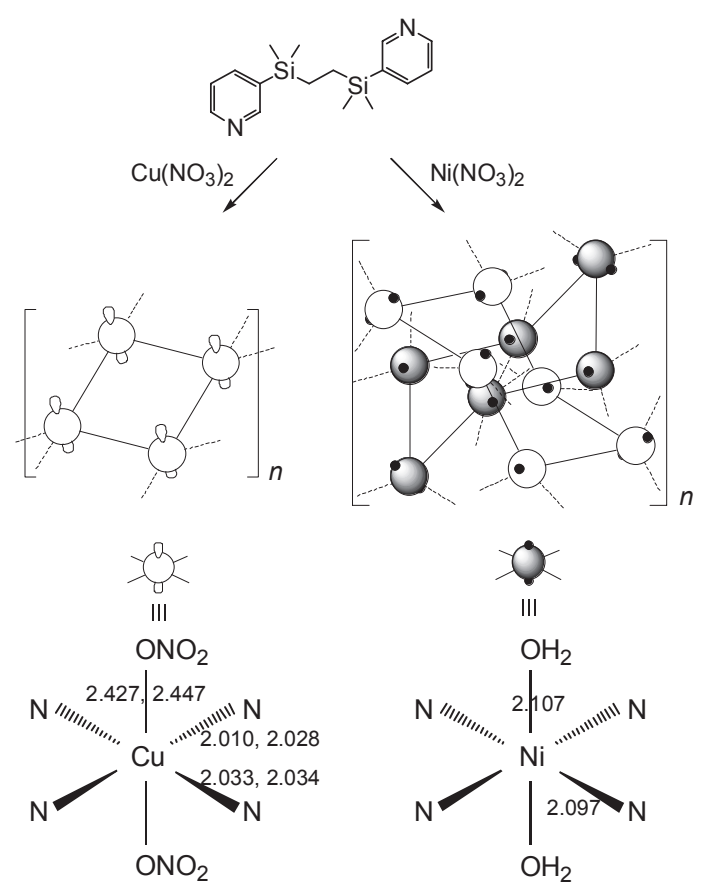

Scheme 1

diagonal $\mathrm{Cu} \cdot \mathrm{Cu}$ distance is $16.834(1) \AA$. The local geometry around the $\mathrm{Cu}(\mathrm{II})$ atom is a typical octahedral arrangement of four $\mathrm{Cu}-\mathrm{N}$ bonds $(2.010(7)-2.034(7) \AA)$ in the basal plane $\left(\mathrm{N}-\mathrm{Cu}-\mathrm{N}=88.8(4)-91.8(4)^{\circ}\right)$ and two $\mathrm{Cu}-\mathrm{ONO}_{2}$ bonds $(2.427$ (6) $\AA$ ) in the axial position. Thus, the nitrate acts as a coordinating ligand rather than a counteranion. Four pyridyl groups around the copper(II) ion are twisted from the basal plane to form a propeller-like conformation (the dihedral angles: 45.5(2) $\left.67.0(5)^{\circ}\right)$. The crystal is composed of $a b a b \cdots$ packed sheet layers along the $c$-axis. The distance between the two layers is 8.194(1) $\AA$, where there is no any significant interaction between the two layers (Figure 2). Two solvated methanol molecules are positioned in the vacant sites.

The crystal structure of $\left[\mathrm{Ni}(\mathrm{L})_{2}\left(\mathrm{H}_{2} \mathrm{O}\right)_{2}\right]\left(\mathrm{NO}_{3}\right)_{2}$ is an interpenetrated network $6^{6}$-isf ${ }^{27}$ consisting of cyclohexanoid $\left(\mathrm{M}_{6} \mathrm{~L}_{6}\right)$ unit with 2-fold interpenetration of class IIa as shown in Figures 3 and 4. The relevant bond distances and angles are listed in
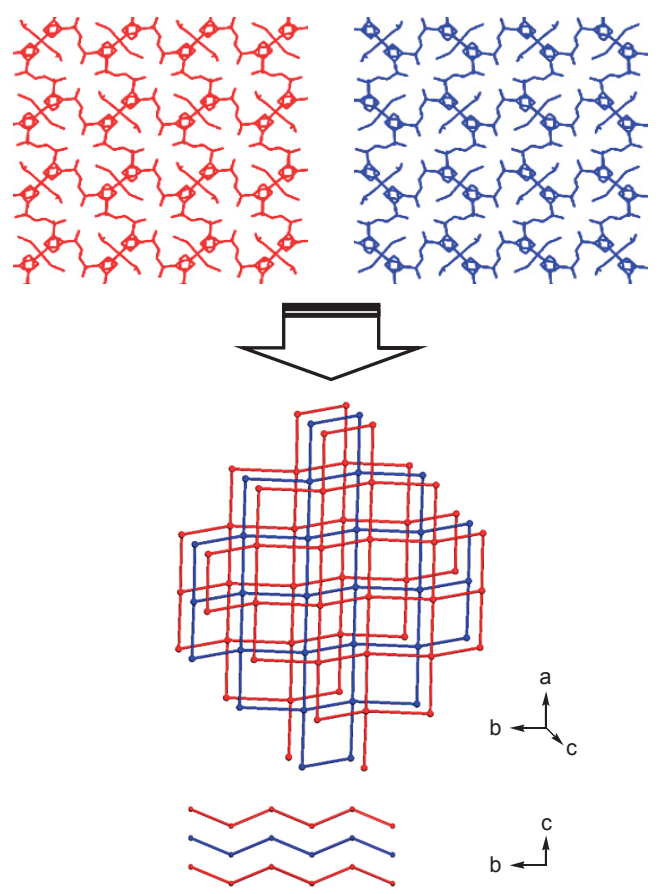

Figure 2. Infinite structure and schematic drawings of $\left[\mathrm{Cu}\left(\mathrm{NO}_{3}\right)_{2}(\mathrm{~L})_{2}\right]$. $2 \mathrm{CH}_{3} \mathrm{OH}$

Table 2. Each L connects two Ni(II) ions in a transoidal fashion, and the local geometry around the $\mathrm{Ni}$ (II) atom is a typical octahedral arrangement of four Ni-N bonds $(2.097(4) \AA)$ in the basal plane $\left(\mathrm{N}-\mathrm{Ni}-\mathrm{N}=89.2(2)-90.9(2)^{\circ}\right)$ and two $\mathrm{Ni}-\mathrm{OH}_{2}$ bonds (2.107(5) $\AA$ ) in the axial position. The nitrate acts as a simple counteranion rather than a coordinating anionic ligand (the shortest $\left.\mathrm{Ni} \cdots \mathrm{ONO}_{2}=4.289(9) \AA\right)$, in contrast to $\left[\mathrm{Cu}\left(\mathrm{NO}_{3}\right)_{2}\right.$ $\left.(\mathrm{L})_{2}\right] \cdot 2 \mathrm{CH}_{3} \mathrm{OH}$. The $\mathrm{Ni} \cdot \cdots \mathrm{Ni}$ separation through $\mathrm{L}$ is $12.161(1) \AA$, and the longest intracyclohexanoid $\mathrm{Ni} \cdots \mathrm{Ni}$ separation is 25.937 (1) $\AA$. The interesting feature is that the crystal structure shows the occurrence of the interpenetration of two 3-dimensional structures through the cyclohexanoidal 66-membered rings.

Construction principle. A combination of octahedral M(II) ions and the appropriate length, conformation, and steric effects of L ligand is needless to say an important factor for the formation of the coordination polymeric species. Each skeleton was exclusively constructed irrespective of the mole ratio of 
(a)

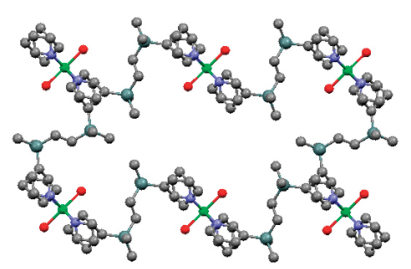

(b)

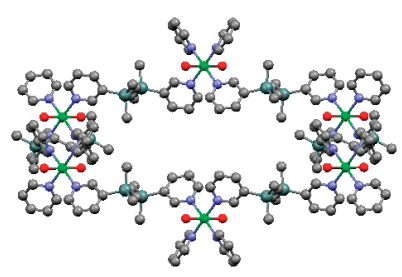

(c)

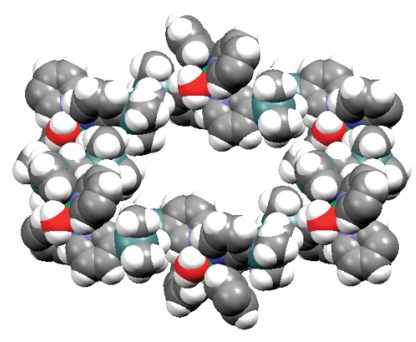

(d)

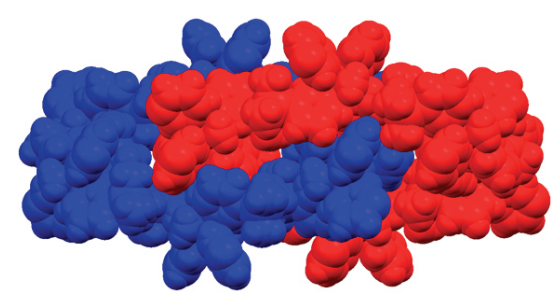

Figure 3. Ball-and-stick drawings in $c$-axis (a) and $a$-axis (b) view, the space-filling drawing (c), and the interpenetrated diagram of cyclohexanoidal skeleton of $\left[\mathrm{Ni}(\mathrm{L})_{2}\left(\mathrm{H}_{2} \mathrm{O}\right)_{2}\right]\left(\mathrm{NO}_{3}\right)_{2}$. Hydrogen atoms, except for (c) and (d), and nitrate molecules have been omitted for clarity.
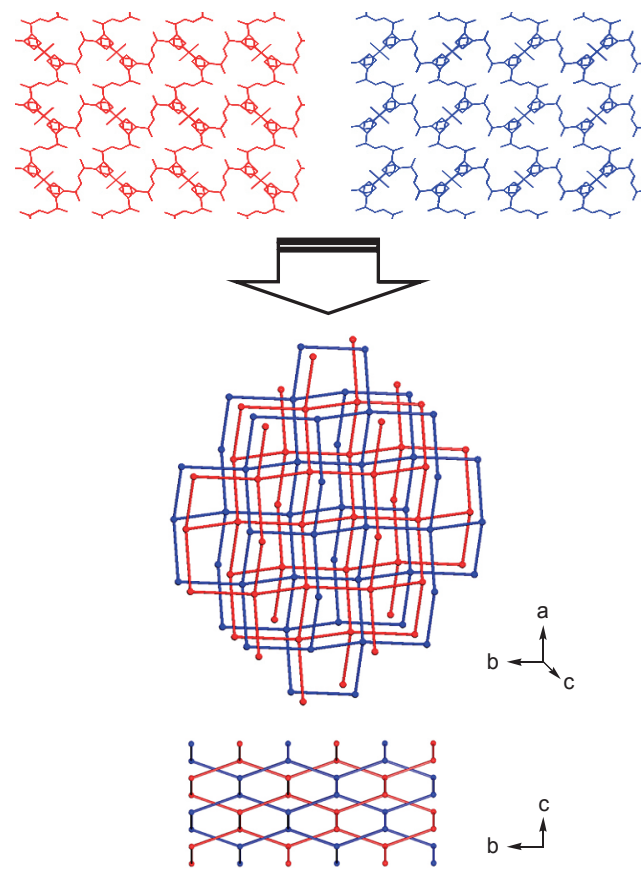

Figure 4. Infinite structure and schematic drawings of two 3-dimensional networks consisting of $\left[\mathrm{Ni}(\mathrm{L})_{2}\left(\mathrm{H}_{2} \mathrm{O}\right)_{2}\right]\left(\mathrm{NO}_{3}\right)_{2}$.

reactants, the solvent types, and the concentrations. The delicate structures seem to be depending on the coordinating nature of metal(II) ions. Thus, the copper(II) ion prefers nitrate whereas the nickel(II) ion prefers water molecules as the fifth and the sixth ligands. The reaction of copper(II) with L provides a 2-dimensional structure whereas the same treatment of nickel(II) with $\mathrm{L}$ yields the interpenetrated 3-dimensional structure. That is, the coordinating nature of metal(II) ions is a crucial factor in controlling structural properties including molecular dimension. In particular, for $\left[\mathrm{Cu}\left(\mathrm{NO}_{3}\right)_{2}(\mathrm{~L})_{2}\right] \cdot 2 \mathrm{CH}_{3} \mathrm{OH}$, a rectangular unit forms, even though $\mathrm{L}$ acts as a similar transoidal conformation. The formation of rectangular unit may be ascribed to the different dihedral angles $\left(71.6(2)^{\circ}\right.$ for 11.382(1) $\AA ; 3.2(5)^{\circ}$ for $12.491(1) \AA$ ) between the two pyridyl groups of a ligand. Another significant factor controlling the self-assembled structures is the weak electrostatic interaction between metal(II) and anions: the coordinated bulky $\mathrm{NO}_{3}{ }^{-}$hampers the interpenetration, whereas the less bulky $\mathrm{H}_{2} \mathrm{O}$ affords the interpenetration. The coordinating character results from the ligand field environment provided by the different donations including steric effects. For $\left[\mathrm{Cu}\left(\mathrm{NO}_{3}\right)_{2}(\mathrm{~L})_{2}\right]$, long distance of $\mathrm{Cu}-\mathrm{ONO}_{2}$ in contrast to $\mathrm{Ni}-\mathrm{OH}_{2}$ distance may be an example of Jahn-Teller effect in a $\mathrm{Cu}^{\text {II }} d^{9}$-system. ${ }^{28}$

\section{Conclusions}

The spacer $\mathrm{L}$ is a transoidal tectonic unit without any particular strain in the construction of two skeletons. The significant structural difference may be indebted to the metal coordinating nature rather than the non-rigid spacer L. In particular, for the present system, the metallophilicity of nitrate and water donors is a very important factor in the construction of molecular skeleton. Further experiments and pervasive applications are in progress, the results of which will yield more detailed information.

Acknowledgments. This work was supported financially by a grant from the fundamental R\&D program for core technology of materials funded by the Ministry of Knowledge Economy, Republic of Korea.

\section{References}

1. Stang, P. J.; Olenyuk, B. Acc. Chem. Res. 1997, 30, 502.

2. Jones, C. J. Chem. Soc. Rev. 1998, 27, 289.

3. Slone, R. V.; Yoon, D. I.; Calhoun, R. M.; Hupp, J. T. J. Am. Chem. Soc. 1995, 117, 11813.

4. Gale, P. A. Coord. Chem. Rev. 2001, 213, 79.

5. Fujita, M. Chem. Soc. Rev. 1998, 27, 417.

6. Jung, O.-S.; Kim, Y. J.; Lee, Y.-A; Park, J. K.; Chae, H. K. J. Am. Chem. Soc. 2000, 122, 9921.

7. Pykkö, P. Chem. Rev. 1997, 97, 597.

8. Orr, G. W.; Barbour, L. J.; Atwwod, J. L. Science 1999, 285, 1049.

9. Bradshow, D.; Claridge, J. B.; Cussen, E. J.; Prior, T. J.; Rosseinsky, M. J. Acc. Chem. Res. 2005, 38, 273.

10. Li, H.; Eddaoudi, M.; O'Keeffe, M.; Yaghi, O. M. Nature 1999, $402,276$.

11. Abrahams, B. F.; Hoskins, B. F.; Michail, D. L.; Robson, R. Nature 1994, 369, 727.

12. Chui, S. S.-Y.; Lo, S. M.-F.; Charmant, J. P. H.; Orpen, A. G.; Williams, I. D. Science 1999, 283, 1148.

13. Batten, S. R.; Robson, R. Angew. Chem., Int. Ed. 1998, 37, 1460.

14. Albrecht, M. Angew. Chem., Int. Ed. 1999, 38, 3463.

15. Kiang, Y.-H.; Gardener, G. B.; Lee, S.; Xu, Z. J. Am. Chem. Soc. 2000, 122,6871 . 
16. Braga, D.; Grepioni, F. Acc. Chem. Res. 2000, 33, 601.

17. Schmidtchen, F. P.; Berger, M. Chem. Rev. 1997, 97, 1609

18. Lapointe, R. E.; Roof, G. R.; Abboud, K. A.; Klosin, J. J. Am. Chem. Soc. 2000, 122, 9560 .

19. Mason, S.; Cliford, T.; Seib, L.; Kuczera, K.; Bowman-James, K. J. Am. Chem. Soc. 1998, 120, 8899.

20. Jung, O.-S.; Kim, Y. J.; Lee, Y.-A.; Chae, H. K.; Jang, H. G.; Hong, J. Inorg. Chem. 2001, 40, 2105.

21. Jung, O.-S.; Lee, Y.-A.; Kim, Y. J.; Hong, J. Cryst. Growth Des. 2002, 2, 497.

22. Jung, O.-S.; Kim, Y. J.; Lee, Y.-A.; Kang, S. W.; Choi, S. N. Cryst. Growth Des. 2004, 4, 23.

23. Lee, Y.-A.; Kim, S. A.; Jung, S. M.; Jung, O.-S.; Oh, Y. H. Bull.
Korean Chem. Soc. 2004, 25, 581.

24. Schmitz, M.; Leninger, S.; Fan, J.; Arif, A. M.; Stang, P. J. Organometallics 1999, 18, 4817.

25. Kwon, J. A.; Jung, H. J.; Jung, O.-S.; Lee, Y.-A. J. Mol. Struct. 2008, 878,60 .

26. Sheldrick, G. M. SHELXS-97: A Program for Structure Determination; University of Göttingen, Germany, 1997; Sheldrick, G. M. SHELXL-97: A Program for Structure Refinement; University of Göttingen, Germany, 1997.

27. Delgado-Friedrichs, O.; O'Keeffe, M. Acta Cryst. 2005, A61, 358.

28. Shriver, D. F., Atkins, P. W., Overton, T. L., Rourke, J. P., Weller, M. T., Armstrong, F. A., Eds.; Inorganic Chemistry, 4th ed.; Oxford University Press: UK, 2006; p 467. 